GEFAD / GUJGEF42(2): 955-992(2021)

\title{
Okul Yöneticilerinin ve Öğretmenlerin Görüşlerine Göre Öğretmen Liderliği: Fenomenolojik Bir Çalışma*
}

\section{School Administrators and Teachers' Views on Teacher Leadership: A Phenomenological Study}

\author{
Özge AYVALI ${ }^{1}$, Didem KOŞAR ${ }^{2}$ \\ ${ }^{1}$ Başkent Üniversitesi, Yabancı Diller Yüksekokulu, Yabancı Diller Bölümü. \\ ozgeayvali17@gmail.com \\ ${ }^{2}$ Hacettepe Üniversitesi, Eğitim Fakültesi, Eğitim Bilimleri Bölümü \\ didemkosar@hacettepe.edu.tr
}

Makalenin Geliş Tarihi: 06.04.2021

Yayına Kabul Tarihi: 20.04.2021

$\ddot{O} Z$

Bu araştırmanın amacı okul yöneticilerinin ve öğretmenlerin öğretmen liderliğine ilişkin görüşlerinin incelenmesidir. Bu çalışma nitel araştırma yöntemi ve fenomenoloji deseni ile yürütülmüşı̈rr. Araştırmanın katılımcı grubunu Ankara'da kamu ve özel ilkokullarda görev yapmakta olan 10 ögretmen ile altı okul yöneticisi oluşturmaktadır. Araştırmada araştırmacılar tarafindan geliştirilen yarı yapılandırılmış görüşme formu kullanılmıştır. Araştırma sonucunda öğretmen liderliğinin meslektaşlarla işbirliği, karara katılım, paylaşımcı olma, değişime ve yeniliklere öncülük etme, rehber olma, rol model olma gibi kavramlarla ilişkilendirildiği görülmekle birlikte öğretmen liderlerin bürokratik, yönetici tutumu gibi çeşitli engellerle de karşılaştıkları sonucuna ulaşılmıştır. Bu bağlamda öğretmenlerin liderlik davranışlarının artması amacı ile onları desteklemek, bu becerilerini ortaya koyabilecekleri ve geliştirebilecekleri bir okul kültürü yaratmak önerilebilir.

Anahtar Sözcükler: Liderlik, Öğretmen liderliği, Okul yöneticisi, Öğretmen.

\footnotetext{
* Alıntılama: Ayvalı, Ö. ve Koşar, D. (2021). Okul Yöneticilerinin ve Öğretmenlerin Görüşlerine Göre Öğretmen Liderliği: Fenomenolojik Bir Çalışma. Gazi Üniversitesi Gazi Eğitim Fakültesi Dergisi, 41(2), 955-992.

** Bu çalışma Hacettepe Üniversitesi Eğitim Bilimleri Enstitüsünden Doç. Dr. Didem KOŞAR danışmanlığında tamamlanan yüksek lisans tezinden üretilmiştir.
} 


\begin{abstract}
The aim of this study is to examine the opinions of school administrators and teachers on teacher leadership. This study was conducted with qualitative research method and phenomenology design. The participant group of the study consists of 10 teachers and six school administrators working in public and private primary schools in Ankara. Semi-structured interview form developed by the researchers was used in the study. As a result of the research, it was found that teacher leadership was associated with concepts such as collaboration with colleagues, participation in decisions, sharing, pioneering change and innovation, being a guide, and being a role model, but it was concluded that teacher leaders also faced various obstacles such as bureaucratic and administrative attitudes. In this context, it can be suggested to support teachers in order to increase their leadership behavior and to create a school culture where they can reveal and develop these skills.
\end{abstract}

Keywords: Leadership, Teacher leadership, School administrator, Teachers

\title{
GíRiş
}

Bir ülkenin gelişmişlik düzeyi, o ülke vatandaşlarının almış oldukları eğitimin niteliği ile doğru orantılıdır. Bu nedenle standartları yüksek bir toplum için donanımlı ve bilgili bireyler yetiştirmenin en önemli anahtarlarından biri eğitimdir. Eğitimin en işlevsel düzeye getirilip uygulanmasında önemli role sahip olan, bilginin geliştirilmesi ve aktarılmasını sağlayan ve topluma rehberlik eden öğretmenlerdir (Elmas, 2018; Günkör, 2017). Öğretmenin niteliği ve yeterliliği eğitim çıktılarını doğrudan etkileyen öneme sahiptir. Bu nedenle öğretmen niteliğini artırmak, öğretmenlerin toplumdaki rolünü ve liderlik özelliklerinden yararlanılmasını ön plana çıkarmaktadır (Can, 2014, s.76). Öğretmen liderliği, öğretmenin bilgiyi aktarma rolünü bilgiyi yeni bilgi elde etmek için kullanma rolü olarak değiştirmektedir (Özden, 2005, s.68). Öğretmen liderliği anlayış1, öğretmenin sınıf içinde etkili olmasını savunan klasik bakışın aksine öğretmenin sınıfla ve okulla ilgili olan tüm uygulamalarda lider olmasının, karar alma süreçlerine katılmasının, rehberlik etmesinin, mesleki açıdan kendini sürekli geliştirmesinin eğitimöğretim hedeflerine ulaşmada etkili olacağını savunmaktadır (Çelik, 2008). Öğretmen liderlerin asıl hedefi öğrenci akademik başarısını ve okul gelişimini en üst noktaya taşıyabilmektir. Öğretmen liderler, sınıfın içinde ve dışında ön plana çıkan, meslektaşlarıyla işbirliği içinde çalışan, eğitim-öğretim konusundaki gelişmeleri takip eden ve bunları sınıf içinde ve dışında hayata geçirip uygulayabilen kişilerdir (Koşar, 
Er, Kılınç ve Koşar, 2017). Can’ın (2014) tanımına göre öğretmen liderliği, öğretimsel vizyon geliştirerek ve paylaşarak sınıf etkinliklerini etkili olarak düzenleyebilme, okul etkinliklerinde işlevsel düzeyde roller üstlenebilme ve geliştirebilme yeteneğidir. Sonuç olarak, gelişme ve yenileşme süreçlerinin en etkili ve verimli şekilde uygulanabilmesi için en önemli faktörlerden biri öğretmenlerin liderlik rolleri üstlenerek uygulayıcı olması ve karar alma süreçlerine katılmasıdır (Mayo, 2002). Öğretmen liderliği; Lambert'a (1998) göre bir kişinin sahip olduğu mesleki pozisyona göre oluşmayan, meslektaşlar arasında paylaşılabilen bir olgudur. Özdemir ve Kılınç'a (2015) göre ise öğretmen liderliği sadece söyleneni uygulayan değil aynı zamanda düşünen, kendini mesleki anlamda geliştirmek için araştıran ve sorgulayan öğretmen anlamına gelmektedir. Katzenmeyer ve Moller (2013) öğretmen liderliğini, öğretmenlerin meslektaşlarıyla işbirliği hâlinde çalışmaları ve bunun sonucu olarak okulun eğitim kalitesi ve başarısına etkili bir biçimde katkı sağlaması, bilgi birikimleri ve uzmanlıklarıyla sınıf içinde ve dışında eğitim kalitesini artırmak adına etkili öğretim yöntemlerini bulup uygulama olarak açıklamaktadır. Tüm bu tanımlardan yola çıkarak, öğretmen liderliğine öğretmene karşı uzun yıllar içinde oluşan geleneksel bakış açısının aksine öğretmenin yapabileceklerine gelişim, değişim, sorgulama, yönetime ve karar verme sürecine katılma gibi roller eklendiği görülmektedir (Kılınç, 2016, s. 77).

\section{Öğretmenlerin Liderlik Rolleri}

Geleneksel liderlik anlayışında liderlik formel gücü ve yetkiyi elinde bulunduran kişilerle ilişkilendirilmiştir (Harris, 2003; Frost ve Harris, 2003). Oysa bu anlayış liderliğin paylaşılması fikri ile önemini kaybetmiştir (Katzenmeyer ve Moller, 2013). Paylaşılan ve işbirliğiyle yürütülen liderlik ile örgütlerde dağıtımcı ve paylaşımcı liderlik yaklaşımlarının daha fazla vurgulanması ve takım ruhunun beslenmesi önem kazanmaktadır (Frost ve Harris, 2003). Öğretmen liderlerin temel rolleri eğitim ve öğretim faaliyetlerinin daha etkili olması için etkili öğrenme yollarının ortaya konmasıdır (Murphy, 2005). Mangin (2005) ve Burgess ile Bates'e (2010) göre öğretmen liderlerin en önemli rolü eğitim ve öğretim etkinlikleri kapsamında belirlenen amaçlara en hızlı ve verimli şekilde ulaşma ve bu doğrultuda öğretmenler arası 
işbirliğini güçlendirme ve meslektaşları motive etmedir. Buna ek olarak Can (2007) öğretmen liderlerin rolleri arasında örgütsel vatandaşlık davranışları sergilemenin, çevrelerini etkileyerek kişileri motive etmenin, eğitim ve öğretim etkinliklerinde yeni projeler üretmenin bulunduğunu ifade etmiştir. Katzenmeyer ve Moller (2013) ile Harris (2002) de öğretmen liderlerin sadece sınıf içinde değil sınıfın dışında da formel ve informel rollerini devam ettirdiklerini, liderlik davranışlarını sürdürdüklerini, meslektaşlarını yeni yöntem ve teknikleri öğrenmeleri konusunda güdüleyip paylaşımcı ve işbirlikçi bir ortam yaratma, okullarını öğrenen bir örgüt haline getirme çabası içinde olduklarını belirtmişlerdir. Conley (1993) bu rolleri uzmanlık alanında ortaya çıkan yenilikleri takip ederek meslektaşlarıyla paylaşmak dolayısıyla okulun gelişimine katkıda bulunmak olarak belirtmiştir. Harris ve Mujis (2005) yine hem kendilerinin hem meslektaşlarının mesleki gelişimlerinin önemine vurgu yaparak öğrencilerin akademik başarısını da destekleyecek şekilde uygulamalar yapmak gerekliliğini eklemiştir. Harris ve Lambert (2003) ise öğretmen liderlik rollerinin meslektaşlar arası işbirliğgi oluşturmak, oluşan yeniliklere karşı okulu hazır hale getirmek ve örgütün kapasitesinin artırılmasına katkı sağlamak olduğunu ifade etmişlerdir. Can (2009) öğretmen liderlerin çevrelerine alanlarında uzman olduklarını kanıtlayarak güven veren, merakı daima yüksek olan böylelikle de kendini sürekli yetiştirmeyi ve geliştirmeyi hedefleyen bir tutum içerisinde olduklarını vurgularken Silva, Gimbert ve Nolan (2000) müdürlük, uzman öğretmenlik ve bölüm başkanlığı gibi yönetsel rollerine vurgu yapmıştır. Millwater ve Ehrich (2009) öğretmen liderlerin mesleki gelişime destek rollerini mentorluk olarak adlandırmışlar; mentorluk rolleri dışında, genel kültürü geliştirmeye ve yenileştirmeye çalışma ve okulda karar alma süreçlerine katılmayı da eklemişlerdir. Beycioğlu (2009, s.40) ise geleneksel öğretmenin daha çok günlük rutin işlere odaklandığını, var olan kaynakları kullanma eğiliminde olduklarını, standart iş davranışlarına ilişkin olarak daha çok işbirliğine kapalı olduklarını, örgüt kültürünün gelişiminden ziyade var olan yapısına uygun hareket ettiklerini, liderlik güçlerini hiyerarşiden aldıklarını ifade etmiştir. Lider öğretmenin ise var olan sistemi geliştirmek için uzun vadeli amaçlara odaklandığını, işbirlikçi davranış ve tutum sergilediğini, tüm süreçlerde karar aşamasında yer alma eğiliminde olduğunu, örgüt için yeni anlamlar ve 
yaklaşımlar yaratma çabasında olduğunu, sınıf içi liderlik gücünü sınıftan ve kültüründen aldığını belirtmiştir. Harrison ve Killion (2007) ise öğretmen liderlerin kaynak sağlama, öğretim sorumlusu, müfredat uzmanı, sınıf destekleyicisi, öğrenme kolaylaştırıcısı, mentor, okul lideri, veri koçu, değişim katalizörü ve öğrenci gibi okul başarısını da etkileyen çok farklı ve çeşitli rolleri olduğunu ileri sürmektedirler.

Sonuç olarak yukarıda belirtilen çalışmalar ışığında öğretmen rolleri arasında mesleki gelişim konusunda yenilikleri takip ederek ve işbirliği içinde güdüleyici olmanın öne çıktığını söylemek mümkündür. $\mathrm{Bu}$ role ek olarak ise okulun başarısını artırma dolayısıyla okul etkililiğini sağlama, okulu öğrenen örgüt hâline getirme konusunda dönüşümsel ve öğretimsel liderlik sergileme göze çarpmaktadır.

\section{Öğretmen Liderliğini Destekleyen Unsurlar}

Okul yöneticilerinin okulu öğrenen bir örgüte dönüştürme konusundaki çalışmalar öğretmen liderliğini destekler ve okulda yeniden yapılanma sağlamasına katkıda bulunur. Öğretmenlerin liderlik davranışlarının desteklenmesi ve liderlik rollerinin oluşturulabilmesi işlevseldir. Yeniden yapılanma süreçlerinde, öğretmenlerin karşılaştıkları liderlik rolleri sorunlarının ve bunlara yönelik çözüm önerilerinin belirlenmesi öğretmen liderliğinin geliştirilmesine katkıda bulunur (Beycioğlu, 2009). Ayrıca bu yeniden yapılanmayı sağlamak için öğretmenler arası işbirliğinin sağlanması ve ortak çalışmalar yapılması, öğretmen liderlerin kendilerini mesleki anlamda geliştirebilmeleri için firsatlar sunulması, aynı zamanda öğretmen liderlerin hem meslektaşları hem de okul yöneticileri tarafından desteklenmesi ve son olarak da öğretmen liderlerin elde ettiği başarılar karşısında ödüllendirilmesi gerekmektedir. (Harris ve Muijs, 2005). Can (2006b) okul kültürünün öğretmen liderliğini destekleyen önemli bir unsur olduğunu belirtmiştir. Okulda yerleşmiş olumlu iletişim, işbirliği, sanatsal ve bilimsel etkinlikler geleneği var ise öğretmenler liderlik yapma konusunda kendilerini daha cesaretli ve girişken hissederler. Harris ve Muijs (2005) öğretmen liderliğinin gelişimini güçlendirecek etmenleri destekleyici kültür, destekleyici yapı, güçlü bir liderlik, eylem araştırması, yenilikçi mesleki gelişim, gelişim çabalarında koordinasyon, yüksek düzeyde öğretmen katılımı, ortaklaşa yaratıcılık, paylaşılan 
mesleki uygulamalar, tasdik etme ve ödüllendirme olarak belirtmişlerdir. Buna göre öğretmen liderliğini destekleyen unsurlardan birisi okul kültürüdür. Okulda var olan destekleyici, işbirlikçi ve olumlu bir ortam öğretmen liderlerin ortaya çıkmasında, sürdürülmesinde önem taşımaktadır. Aynı zamanda üst yönetim ile çalışanlar arasında toplantılar, hiyerarşiyi kıracak paylaşımlar öğretmen liderliğini geliştirecektir. Okul yönetiminin öğretmenleri destekleyici tutum, davranış ve sözleri, rehberlikleri, başarıyı artırmaya yönelik çalışmalar ve araştırmalar içerinde yer almak, meslektaşlar arası işbirliği, dayanışma, ortak amaç etrafında birlikte çalışma kültürü, kararlara katılım olanağı, fikir görüş öneri alışverişleri ile ekip çalışmaları, ödüllendirme öğretmen liderliğini desteklemektedir.

\section{Okul Yönetiminin Öğretmen Liderliğine Etkisi}

Öğretmen liderler demokratik ve çağdaş bir yönetim anlayışının olduğu, paylaşımcı liderlik özelliklerinin görüldüğü okullarda kurumun gelişmesine daha çok katkıda bulunabilirler (Aslan,1989, Akt. Beycioğlu, 2009). Okul yöneticilerinin paylaşımcı liderlik çerçevesinde yetkilerini ve güçlerini öğretmenlerle paylaşmaları, onları karar alma sürecine dâhil etmeleri, öğretmenler arasında işbirliğinin sağlamaları, geliştirilmiş öğretim uygulamalarıla birlikte öğretmenlerle sağlanan işbirliği sayesinde okulun kapasitesinin artırılması okullardaki öğretmen liderliği olgusunun oluşmasına daha fazla olanak sağlar (Özdemir, 2013). Can’a (2006b) göre öğretmen liderlerin geliştirilmesi için müdürlerin uygulaması gereken stratejiler; öğretmenleri gelişime teşvik eden bir atmosfer oluşturmak, ilgi ve gereksinimlerinin farkında olup onları karşılamak, üretkenlik konusunda motive etmek, okulda etkili öğretimi destekleyici bir atmosfer yaratarak işbirlikçi ilişkileri özendirmek ve başarının sonucunda ödüllendirme sayesinde öğrenci etkili öğrenmesini sağlamak olarak ifade edilmektedir. Buckner ve Mc Dowelle (2000) müdürlerin öğretmen liderliğini geliştirmede öğretmen liderliğini tanımlama, aday liderlere formel ve informel öğretmen liderliğini açıklama, öğretmen liderlerle ilişkilerinde rahat ve açık olma, öğretmenleri değerli yetenekler olarak görme ve lider olmaya özendirip teşvik etme, öğretmenlere liderlik becerilerini geliştirmede yardımcı olma, öğretmen liderlere dönüt sağlama rollerini yerine getirebileceğini 
belirtmektedir (Akt. Can, 2006b). Crowther, Ferguson ve Hann (2009) öğretmen liderliğini etkinleştirmek için müdürlerin önem vermesi gereken yedi mücadele alanını stratejik amacı aşılama, diğerlerinin görüşlerini ve isteklerini dâhil etme, cevaplaması sor olan sorular karşısındaki duruş, bireysel yenilik için yer açmak, ne zaman geri adım atacağını bilmek, algılanan sıkıntılar için firsatlar yaratmak, başarı kültürü yaratmak için başarıyı inşa etmek olarak belirlemişlerdir. Bu doğrultuda okul müdürleri okul kapasitesini artırmak amaçlı fikir, görüş ve önerilerini şeffaf bir şekilde paylaşmalı, yenilikler için çalışanlarını etkilemelidir. Okul müdürleri öğretmenlere karara katılım konusunda destekleyici bir tutum içerinde olursa öğretmenlerini gözlemlediğinde lider öğretmenlerin ayrımına varabilecektir. Aynı zamanda okul müdürleri öğretmenlere çeşitli sorular yönelterek kendilerini nasıl ifade edebileceklerine ilişkin firsatlar sunarak lider öğretmenleri fark edebilirler. Okul müdürleri öğretmenlerin bireysel farklılıklarından doğan yeteneklerini ortaya çıkarmak için onları teşvik etme ve gelişimlerine olanak sağlama durumundadır. Öğretmen liderler karar alma süreçlerine dâhil olsalar bile formel yetkiye sahip değildir. Bu nedenle okul müdürleri öğretmenleri öğretmen liderliğine teşvik etmek için bazen geri adım atarak yetkilerini devretmelidirler. Okul müdürleri risk alarak faaliyetlerine devam eden öğretmen liderleri hatalı bir duruma düştüklerinde ya da problemli bir durumla karşılaştıklarında yalnız hissetmemeleri adına güven kültürünü inşa etmelidirler. Başarının bir kültür olarak okullarda yer edinmesi okulların toplumdaki etkisini ve başarı sayesinde öğretmenlerin güdülenip liderlik kapasitelerini ortaya çıkarmasını sağlar.

\section{Öğretmen Liderliğinin Engelleri}

Can (2006a) öğretmen liderliğinin engellerine okul kültürünü, mesleksel yetişme sürecindeki yetersizliği, lider yerine yönetici müdürleri, yönetim desteğinin yetersizliği, zaman sınırlılığ1, öğretmenin formel yükü, diğer öğretmenlerin yetersiz desteği, yetişme ve gelişme ortamının yetersizliği, etkinlik ve kazanımların tam değerlendirilmemesi, meslek sevgisi ve heyecanında azalma, sınav odaklı eğitim sistemi, kalabalık sınıfları, bürokratik engelleri, ücret yetersizliğini, eğitim teknolojisindeki yetersizliği, fiziksel ortam ve olanaksızlıkları, ders programları ve yıllık planları yetiştirme zorunluluğunu 
örnek vermektedir. Aynı öğretmen özerkliğinin yetersizliğini sınıf içerisinde uygulamalar konusunda fikirlerinin alınmaması da engeller arasında yer almaktadır. Can lider olan ve olmayan öğretmen çatışmalarına vurgu yaparak lider öğretmenin diğer öğretmenler tarafından anlaşılmamasını ve bu nedenle yalnız kalmasına işaret etmektedir. Araşkal ve Kılınç (2019) yapmış oldukları çalışmalarında öğretmen liderlerin karşılaştıkları sorunların başında yönetici desteğinin yetersizliğini, okul yöneticilerinin aşırı şekilde öğretmenleri yasa, yönetmelik ve genelgelerle sınırlandırmak istemelerini belirtmişlerdir. Aynı zamanda çalışmada meslektaşların eşitlikçi normlarının öğretmen liderliği için engel olduğunu sonucuna ulaşılmıştır. Katılımcılar tüm öğretmenlerin mesleklerinde eşit olduğu algısını taşıdıkları ve aralarından bir öğretmenin lider olarak ortaya çıkmasının bu norma zarar vereceği yönünde görüş bildirmişlerdir. Öğrenci, öğretmen, veli ve yönetici gibi eğitim öğretim süreçlerinde yer alan tüm paydaşların akademik başarıya aşırı odaklanmış olmaları da yine engellerden bir diğeri olarak söz konusu çalışmada ifade edilmiştir. Moller de (1999) öğretmen liderliği önündeki engelleri şu şekilde belirtmiştir; öğretmenler zamanı iyi organize edemeyerek öğretmen liderliğine yeterli mesaiyi ayırmadıklarında, zaman büyük bir engel olarak karşılarına çıkmaktadır. Lider olmayan öğretmenlerin öğretmen liderlerin daha üst statüde bulundukları şüphesi liderlik potansiyeline sahip öğretmenlerin cesaretini kırmaktadır. Kıdemli öğretmenlerin vazgeçmek istemedikleri yöntem ve alışkanlıklar bir direnç örneği olarak engeller arasında yerini almaktadır. Personel yetiştirmek öğretmen liderliği için en önemli rollerden biridir ve ilk yıllarında olan öğretmen liderler bu anlamda zorluk yaşayabilirler. Çoklu rol sorumluluğuna yetişmeye çalışmak da bir engel olarak kabul edilmektedir. Bazı okul yöneticileri hiyerarşik basamaklara çok fazla bağlı oldukları için lider öğretmenlerin sorumluluk almalarını ve karar verme süreçlerine katılmalarını onaylamamaktadır. $\mathrm{Bu}$ da lider öğretmenlerin liderlik rollerini gerçekleştirebilmeleri için bir engel oluşturmaktadır (Akt. Can, 2006a). Alanyazın incelendiğinde öğretmen liderliğine ilişkin ilginin son yıllarda arttığını görmek mümkündür (Araşkal ve Kılınç, 2019; Balyer, 2016; Beycioğlu ve Aslan, 2012; Işık ve Bahat, 2018; Kılınç, 2014; Kılınç ve Recepoğlu, 2013; Koşar, 2018; Uğurlu ve Yiğit, 2014, Zülfizade, 2020). Çalışmalar incelendiğinde, öğretmen 
liderliğinin okul akademik başarısı için, okulların sosyal etkinliklerdeki gelişimi için önemli ve etkili olduğu görülmektedir. Öğretmen liderliğine ilişkin olarak kamu ve özel ilkokullarda görev yapan öğretmenler ve yöneticiler ile yüz yüze görüşmeler yapılarak yürütülen bu çalışmanın öğretmen liderliğinin önemini ve ne derece uygulandığını açıklamada etkili olacağı düşünülmektedir. Aynı zamanda günümüzde yaşanan ekonomik, sosyal ve politik değişme ve gelişmeler okulların yapılarını ve işleyişlerini birçok açıdan etkilemektedir; bu bağlamda okulda çalışan yönetici ve öğretmenlerin de rolleri değişmektedir. Değişen koşullar, beklentiler ve roller okul çalışanlarının da liderlik rollerini yeniden gözden geçirmelerine sebep olmakta öğretmen liderliği kavramını daha da önemli kılmaktadır. Bu nedenle öğretmen liderliği kavramının anlamını, öğretmen liderlerin sahip olması gereken özellikleri, rollerini ortaya koymak önem kazanmaktadır. Öğretmen yetiştiren yükseköğretim kurumlarındaki eğitim öğretim faaliyetlerinden istihdam edilen öğretmenlerin emekliliklerine kadar süregelen bütün aşamaları bütünsel bir sistemin birbirini etkileyen temel unsurları olarak değerlendirme anlayışı doğrultusunda hazırlanan Öğretmen Strateji Belgesi 20172023 'te 3 amaç belirlenmiştir; bunlar yükssek nitelikli, iyi yetişmiş ve mesleğe uygun bireylerin öğretmen olarak istihdamını sağlamak, öğretmenlerin kişisel ve mesleki gelişimini sürekli kılmak ve öğretmenlik mesleğine yönelik algıyı iyileştirmek ve mesleğin statüsünü güçlendirmektir (Millî Eğitim Bakanlığı [MEB], 2017). 2023 Eğitim Vizyon Belgesi'nde ise öğretmen ve okul yöneticilerinin mesleki gelişimlerinin yeniden yapılandırılması belirlenen amaçlar arasında yer almaktadır; bu doğrultuda mesleki yeterlilikleri yüksek, başarılı öğretmenlerin bilgi ve deneyimlerini artırmaları için yurt dışına gönderilmesi, lisansüstü düzeyde Öğretmenlik Mesleği Uzmanlık Programı’nın açılması, öğretmen ve okul yöneticileri için yatay ve dikey kariyer uzmanlık alanları yapılandırılması, öğretmen ve okul yöneticilerinin mesleki gelişimlerini sürekli desteklemek üzere üniversitelerle ve sivil toplum kuruluşları ile yüz yüze, örgün ve/veya uzaktan eğitim iş birliklerinin hayata geçirilmesi, yükseköğretim kurumlarıyla iş birliği içinde 21. yüzyıl becerilerini kazandırmak üzere ihtiyaç duyulan alanlarda öğretmenlere yönelik lisansüstü düzeyde yan dal programları açılması, Öğretmenlik Meslek Kanunu çıkarılması kararlaştırılmıştır (MEB, 2018). Görüldüğü üzere politika 
belgelerinde öğretmenlerin mesleki gelişimlerini sürekli hale getirmek, öğretmen niteliğinin artırlarak çağa uyum sağlayan nitelikli insan gücünün yetiştirilmesini sağlamak ve bu anlamda öğretmenlerin rol model olmalarına destek olmak hedeflenmiştir. Hem Öğretmen Strateji Belgesi 2017-2023 hem de 2023 Vizyon Belgesi öğretmen liderliğinin benimsenmesi ve tüm öğretmenlerin liderlik davranışlarını ortaya koymalarını sağlama yönünde tüm firsat ve olanakları ortaya koymaktadır. Bu araştırma ile de okul yöneticileri ve öğretmenlerin öğretmen liderliğinin okullarındaki yansımasının ortaya konması hedeflenmiş böylelikle okul yöneticilerine, öğretmenlere ve politika yapıcılara okulların akademik başarılarının artırılmasında, okul kültürünün güçlendirilmesinde, okul etkililiğinde, hazırlanacak olan politika belgelerinde önemli veriler sağlayacağı düşünülmektedir.

\section{Araştırmanın Amacı}

$\mathrm{Bu}$ araştırmanın amacı okul yöneticilerinin ve öğretmenlerin öğretmen liderliğine ilişkin görüşlerinin incelenmesidir. Bu ana amaç doğrultusunda aşağıdaki alt amaçlara cevap aranmıştı; Okul yöneticilerinin ve öğretmenlerin görüşlerine göre, (i) “Öğretmen liderliğinin anlamı nedir?”, (ii) “Öğretmen liderlerin sahip olması gereken özellikler nelerdir?", (iii) “Okullarda öğretmen lider olduğu düşünülen öğretmenlerin sahip olduğu özellikler nelerdir?”, (iv) “Öğretmen liderlerin rolleri nelerdir?”, (v) “Liderlik davranışı gösteren öğretmenlerin okul gelişimine yönelik ne gibi katkıları olmaktadır?”, (vi) "Okullarda öğretmenlerin liderlik özellikleri gösterebilmeleri konusunda karşılaştıkları engeller nelerdir?", (vii) "Öğretmen liderliği geliştirme ve destekleme konusunda öneriler nelerdir?" ve son olarak (viii) "Okul yöneticilerinin öğretmenin liderlik davranışı göstermeleri konusunda katkıları nelerdir?" 


\section{YÖNTEM}

\section{Araştırmanın Modeli}

Kamu ve özel okullarda görev yapmakta olan yönetici ve öğretmenlerin öğretmen liderliğine ilişskin görüşlerinin araştırılmasını amaçlayan bu çalışmada, nitel veri toplama teknikleri ve olgu bilim deseni kullanılmıştır. Nitel araştırma, gözlem, görüşme, doküman analizi kullanılarak nitel verilerin toplandığ sayesinde sonuçların bütüncül bir şekilde ortaya konulduğu bir yöntemdir. Fenomenoloji kişilerin farkında olduğu ancak derinlemesine ve ayrıntılı bir anlayışa sahip olmadığı olgulara odaklanmaktadır. Fenomenoloji çalışmalarında amaç; bireyin bir olguya ilişkin yaşantılarını, algılarını ve buna yüklediği anlamları ortaya çıkarmaktır. Fenomenolojinin kullanıldığı araştırmalarda veri kaynakları araştırmanın odaklandığı olguyu yaşayan veya bu olguyu yansıtabilecek birey veya gruplardır ve olgu bilim araştırmalarında veri toplama araçlarından biri görüşmedir (Yıldırım ve Şimşek, 2006). Bu bağlamda bu araştırma öğretmen liderliğinin bulunabildiği ilkokullarda görev yapmakta olan yöneticiler ve öğretmenler ile görüşme tekniği kullanılarak öğretmen liderliğine ilişkin deneyimlere odaklanarak yürütülmesi sebebi ile fenomenoloji desenindedir.

\section{Araştırmanın Çalışma Grubu}

Araştırmanın çalışma grubunu, 2019-2020 eğitim öğretim döneminde Ankara'daki resmi ve özel ilkokullarda görev yapmakta olan altı okul yöneticisi ve 10 öğretmen oluşturmaktadır. Çalışmada maksimum çeşitlilik örnekleme tekniği kullanılmış, çalışma grubuna seçilecek okul yöneticilerinin ve öğretmenlerin belirlenmesinde cinsiyet, yaş, öğrenim durumu, görev, branş, mesleki kıdem, okuldaki kıdem, görev yapılan okul türü gibi değişkenler çeşitlilik kaynağı olarak alınmış böylelikle çalışma grubunun çeşitliliği sağlanmıştır. Katılımcıların 10'u öğretmen 6'sı okul yöneticisidir. Okul yöneticisi olarak görev yapan katılımcıların 4'ü müdür yardımcısı 2'si okul müdürü olarak görev yapmaktadır. Katılımcıların 12'si kadın, 4'ü erkektir ve yaşları 26 ile 53 arasında 
değişiklik göstermektedir. 4'ü yüksek lisans mezunu, 12'si ise lisans mezunudur. Katılımcıların 1'i İngilizce, 13'ü sınıf öğretmenliği, 1'i özel eğitim ve 1'i PDR branşındadır. Katılımcıların mesleklerindeki kıdem yıllarına bakıldığında 1-9 yıl arası kıdeme sahip 10, 10-19 yıl arası kıdeme sahip 3 ve 20-29 y1l arası kıdeme sahip 3 katılımcının olduğu görülmektedir. Katılımcıların şuan görev yaptıkları okullardaki hizmet sürelerine bakıldığında tüm katılımcıların 1-9 yıl arası hizmette bulundukları görülmektedir. Katılımcıların 10’u kamu, 6’sı özel okulda görev yapmaktadır.

\section{Veri Toplama Aracı}

Araştırmada veri toplama aracı olarak araştırmacı tarafından geliştirilen 7 demografik, 8 açık uçlu sorudan oluşan yarı yapılandırılmış görüşme formu kullanılmıştır. Yarı yapılandırılmış görüşme formu oluşturulurken ilgili alanyazın ayrıntılı olarak taranmış ve ilkokullarda görev yapan yönetici ve öğretmenlerin öğretmen liderliğine ilişkin görüşlerini saptamak amacı ile çeşitli maddeler belirlenerek üç eğitim yönetimi uzmanı görüşüne başvurulmuştur. Uzman incelemesi sonucunda görüşme formunda yer alan sorular uzman görüşleri sonucunda yeniden düzenlenmiş, eksik bulunan maddeler eklenerek ve maddeler üzerinde düzenlemeler yapıldıktan sonra araştırmanın amacına uygun, anlaşılır ve uygulanabilir olacak şekilde görüşme formuna son hâli verilmiştir. Görüşme formunda yer alan bazı sorular; "Öğretmen liderlerin sahip olması gereken özelliklerin neler olabileceğini düşünüyorsunuz?’, “Öğretmen liderlerin rolleri nelerdir?" şeklindedir.

\section{Veri Toplama Süreci}

Çalışma grubunun belirlenmesi ve gerekli yasal izinlerin alınmasının ardından okul yöneticilerine telefon aracılığı ile ulaşılmış ve araştırmanın amacı ve yöntemi hakkında bilgi verilerek görüşme için randevu alınmıştır. Belirlenen randevu gününde ve saatinde görüşmeyi kabul eden yöneticilerin görev yaptıkları okullara gidilerek hem öğretmenlerle hem de yöneticilerle birebir ve yüz yüze görüşmeler yapılmıştır. Bir görüşme yaklaşık olarak 20-30 dakika aralığında sürmüştür. Çalışmada kurum ve şahıs isimlerinin belirtilmeyeceği, verilerin bilimsel amaçla kullanılacağı ve yapılan görüşmelerin sadece araştırmacı tarafından dinleneceği belirtilerek katılımcılardan 
alınan onay ile ses kayıt cihazı aracılığıyla görüşmeler kayıt altına alınmıştır. Kayıt altına alınan her bir görüşmeden elde edilen veriler araştırmacı tarafından dinlenerek Word dosyası şeklinde bilgisayar ortamında yazılmıştır. Hazırlanan görüşme soru ve cevaplarının yer aldığı Word dosyaları, katılımcıların gönüllü katılım formunda belirttikleri mail adreslerine e-posta ile gönderilerek verilerin doğruluğu konusunda kendilerinden teyit alınmıştır.

\section{Etik Kurallara Uygunluk}

Araştırmanın tüm aşamalarında etik kurallara uygun hareket edilmesine özen gösterilmiştir. $\mathrm{Bu}$ çalışma ilk yazarın ikinci yazar danışmanlığında 2021 yılında Hacettepe Üniversitesi Eğitim Bilimleri Enstitüsü’nde tamamlanan yüksek lisans tezi verilerine dayalı olarak hazırlanmıştır. Verilerin toplanmasına yönelik izin için Hacettepe Üniversitesi Etik Komisyonundan izin alınmıştır. Ayrıca veriler Milli Eğitim Bakanlığından da alınan araştırma izni ile gönüllü katılımcılardan toplanmıştır. Etik kurul onayı EK 1'de sunulmuştur.

\section{Geçerlik ve Güvenirlik}

Nitel bir araştırmada toplanan verilerin detaylı bir şekilde rapor edilmesi ve sonuçlara nasıl ulaşıldığının açıklanması geçerlik ve güvenirlik için önemli ölçütlerdir (Yıldırım ve Şimşek, 2016). Geçerlik ve güvenirliğin sağlanabilmesi adına sunulan önlemler arasında; araştırma sürecinin detaylı bir şekilde planlanması ve araştırma konusunda uzman bir kişinin araştırma sürecini izlemesi, araştırmada sorulan soruların yazılı olarak bulunması, bu soruların alana hâkim uzmanlar tarafından incelenmesi, verilerin uzun süreli etkileşim içerisinde elde edilmesi, katılımcıların verdikleri cevapların tekrar incelenebilmesini sağlamak adına kayıt altına alınması ve varılan çıkarımların dayanaklarının belirtilmesi bulunmaktadır. $\mathrm{Bu}$ nedenle çalışma öncesinde araştırma süreci planlanmış ve bu süreç gözlenmiştir. Ayrıca görüşme esnasında sorulacak sorular daha önceden hazırlanıp uzman görüşleri doğrultusunda düzenlenerek, görüşmeler esnasında yazılı bir halde bulundurulmuştur. Katılımcılar ile yapılan görüşmeler, soruları tam olarak anlayabildiklerinden emin olarak ilerlemiş, tüm konuşmalar ses

kayıt cihazları ile kayıt altına alınmıştır. Nitel çalışmaların güvenirliğinin ve 
geçerliliğinin kontrolü için sunulan yöntemler arasında ise, en az bir katılımcının bulguları incelemesi ve teyit etmesi, elde edilen sonuçların sürekli bir biçimde karşılaştırılması ve kontrol edilmesi ve elde edilen sonuçların alanyazın ile uyumlu olması bulunmaktadır. Özetle, iç geçerlik, uzman görüşü, katılımcı teyidi, elde edilen bulguların alıntılarla desteklenmesi, veri toplama aracı olan yarı yapılandırılmış görüsşme formunda yer alan soruların ve bulguların ilgili alanyazın ile tutarlı olması ile dış geçerlik, araştırma yönteminin ve basamaklarının tanımlanması, veri toplama, verilerin analizi ve yorumlama sürecinin betimlenmesi ile iç güvenirlik, sonuçlar ile verilerin tutarlılı̆ğına yönelik tutarlılık incelemesi, dış güvenirlik ise araştırmacının izlediği yöntemleri, veri toplama ve analiz süreçlerini ayrıntılı bir şekilde tanımlaması, bireysel varsayım ve önyargıların araştırmaya yansıtılmaması, toplanan ham verilerin saklanması ile sağlanmaya çalışılmıştır.

\section{Verilerin Analizi}

Verilerin analizinde içerik analizi kullanılmıştır. İçerik analizi insan davranışlarını üzerinde doğrudan olmayan yollarla çalışmaya imkân tanıyan ve sosyal bilimlerde sıklıkla kullanılan bir tekniktir. İçerik analizi birbirine benzeyen verilerin belirli kavramlar, kategoriler ve temalar çerçevesinde bir araya getirilmesi ve anlaşılabilir biçimde düzenlenerek yorumlamaya yardımcı olmasını sağlayan bir yöntemdir. Yönetici ve öğretmenler ile yapılan görüşmeler sonucunda aktarılan veriler kodlanmış, bu kodlar sınıflandırılarak araştırma bulgularını ortaya çıkaracak, bu kodları en iyi şekilde açıklayan temalar/kategoriler belirlenmiş, içerik analizleri yapılmıştır. İçerik analizinde amaç, toplanan verileri açıklayabilecek ilişkilere ve kavramlara ulaşmaktır. İçerik analizinde temelde yapılan işlem, birbirine benzeyen verileri belirli kavramlar ve temalar çerçevesinde bir araya getirmek ve bunları okuyucunun anlayabileceği bir biçimde organize ederek yorumlamaktır (Yıldırım ve Şimşek, 2016). Aynı zamanda katılımcıların görüşlerini yansıtabilmek amacıyla doğrudan alıntılara yer verilmiş, alıntı seçiminde farklı görüşler, açılayıcılık, konuya uygunluk, çeşitlilik ve uç örnekler dikkate alınmıştır (Ünver, Talu-Bümen ve Başbay, 2010). Katılımcıların görüşlerinden 
birebir alıntılar yapılırken, görüşüne başvurulan okul yöneticilerinin ve öğretmenlerin gizliliğini sağlamak açısından cinsiyete uygun isim kodları verilerek kodlanmıştır.

\section{BULGULAR}

\section{Öğretmen Liderliğinin Anlamına İlişkin Görüşler}

Çalışma grubunda yer alan katılımcılara yöneltilen ilk soru "Sizce ögrretmen lider ne anlama gelmektedir?" şeklindedir. Öğretmen liderliğinin ne anlama geldiğinin araştırıldığ 1 bu soruda katılımcıların cevapları incelendiğinde kişisel özelliklere odaklanan ve mesleki özelliklere odaklanan anlam şeklinde iki kategori bulunmuştur. Kişisel özelliklere odaklanan anlam kategorisinde risk alabilen kişi ve ikna edebilen kişi kodları öne çıkarken mesleki özelliklere odaklanan anlam kategorisinde rehberlik edebilen kişi, disiplinli ve yenilikleri takip eden kişi kodları vurgulanmıştır. Ayrıca okul yöneticileri öğrenciye sevgi veren ve pratik çözümler bulan kişiler kodlarında ortak görüş bildirirken öğretmenler öğretmen liderin daha çok girişken ve örnek olan kişi anlamına geldiğini vurgulamışlardır. Mesleki özelliklere odaklanan anlam kategorisi göz önünde bulundurulduğunda ise yöneticilerin daha çok iyi bir gözlemci, kendini geliştiren, paylaşımcı, işbirlikçi kodlarında, öğretmenlerin ise tecrübeli, karizmatik kişiler olarak öğretmen liderleri tanımlamışlardır. Emine öğretmen liderlerin girişken, yenilikleri takip eden ve liderlik özelliklerinden biri olan peşinden sürüklemeyi gerçekleştiren kişiler olarak tanımlanabildiklerini şu sözleri ile belirtmiştir; "Her şeyde kendini öne atan, bir şeyleri araştırmak isteyen, bir şeyler geliştirmek isteyen, arkadaşlarını kendiyle beraber sürükleyebilen, paylaşan”. Osman ise öğretmen liderlerin sevgi veren kişiler olarak nitelendirildiklerini “Öğretmen lider; öğrencilerin duygularını harekete geçirebilen, okula karşı olumlu tutum geliştirmelerini sağlayabilen, belli kuralları onlara aşılayabilen ama bunları aşılarken de sevgi faktörünü geri plana atmadan sevgi ve sorumluluk arasında o çizgiyi doğru bir şekilde oturtabilen bir öğretmen geliyor aklıma." şeklindeki sözleri ile dile getirmiştir. Öğretmen liderlerin mesleki özelliklerine odaklanan anlamına ilişkin vurgulanan kodlardan birisi de yönlendirici olmasıdır. Bu bağlamda katılımcılardan birisi öğretmen 
liderin etkilemesinin önemine, başkalarına iş yaptırabilmesine değinmiştir. $\mathrm{Bu}$ doğrultuda da sözlerini şöyle "Lider öğretmen, yönlendirebilendir. Kendi yapmayan ama yaptırabilen ögretmen. Öğrenciye, veliye de ama öncelik ögrenci.” (Damla) ifade etmiştir. Aynı şekilde okul yöneticisi olarak görev yapmakta olan Muzaffer'in de öğretmen lideri yönlendiren kişi olarak tanımladığı “ Ö̆gretmen liderliğini; öğretmenleri yönlendirme, ĕğitim-öğretimi daha işlenir hâle getirecek çeşitli tedbirlerin, planlamaların yapılması şeklinde algıllyorum.” şeklindeki sözlerinden anlaşılmaktadır.

\section{Öğretmen Liderlerin Sahip Olması Gereken Özelliklere İlişsin Görüşler}

Çalışma grubunda yer alan katılımcılara yöneltilen ikinci soru "Öğretmen liderlerin sahip olması gereken özelliklerin neler olabileceğini düşünüyorsunuz?', şeklindedir. Öğretmen liderlerin sahip olması gereken özelliklerin araştırıldığı bu soruda katılımcıların cevapları incelendiğinde teknik, kişisel ve kavramsal özellikler kategorileri belirlenmiştir. Teknik özellikler kategorisinde okul yöneticileri ve öğretmenler yenilikleri takip eden ve iletişimi iyi, teknolojiyi iyi kullanabilen kodlarında ortak görüş bildirmişlerdir. $\mathrm{Bu}$ kodlar dışında öğretmenlerin öğretmen liderin teknik özelliklerine ilişkin zamanı etkin kullanma, ahlaki değerleri ön planda tutan, tecrübeli ve üretken kodlarında yoğunlaştığı görülürken okul yöneticilerinin daha çok çalışkan, eylemlerinin sonuçlarını takip eden, her seviyeye hitap edebilen kodlarını öne çıkardıkları belirlenmiştir. Kişisel özellikler kategorisinde ise risk alabilen, güvenilir, ikna kabiliyeti olan kodları yöneticiler ve öğretmenler tarafindan daha çok vurgulanmıştır. Bu kodlar dışında öğretmenlerin öğretmen liderin kişisel özelliklerine ilişkin vicdanlı, dürüst, sözünde duran kodlarında yoğunlaştığı görülürken okul yöneticilerinin daha çok yönlendiren, idealist ve kararlı kodlarını vurguladıkları belirlenmiştir. Zeynep öğretmen liderlerin sahip olduğu iletişim becerilerinin önemli olduğunu, bu iletişim becerilerini iyi kullanarak ve rol model olarak iletişimi güçlü öğrenciler yetiştirebileceğini şu sözleri ile belirtmiştir; “Akademik yönden ziyade benim için sosyal becerileri. Günlük yaşamda çocuklar neler yapabiliyor. 'Günaydın' bile demeyen çocuklar. Sonuçta her şekilde ögrenebiliriz. Annesi de ögretebilir, babası da ögretebilir. Ama önemli olan bazı becerileri. Bir yer silen bir insan gördüğünde 'Kolay 
gelsin'” demesini bilsin ya da bir düğme dikilecekse o düğmeyi dikebilsin. Akademik anlamda değil. Hem sosyal hem de davranış açısından bir çocuk yetiştirebilirsek bence lider ögretmen odur. Risk alabilen, vicdanlı, dürüst. İşte bu çocuklarl yetiştirebilirsek ne mutlu." Özlem ise öğretmen liderlerin sürekli kendilerini yenileyen üretken kişiler olduklarının altını çizmiş ve şu sözleri söylemiştir; "En başta sınıf yönetiminin olması gerekir. Daha sonrasında yerinde saymaması lazım. Güncel olması lazım ki çağında da liderlik yapabilsin yani. Özellikle risk alabilen insanlar.” Osman da lider öğretmenlerin teknik özelliklere sahip olması gerektiğini, teknolojiyi iyi bilmeleri gerektiğini bunun öğrencilerle iletişiminde önemli bir nokta olduğunu vurgulamıştır ve şöyle söylemiştir; “Gelişime açık, yenilikçi, idealist, özgüveni yüksek, ikna kabiliyeti yüksek, iletişimi çok kuvvetli olan. Teknolojiye hâkim aynı zamanda, çağımıza hâkim. Yaş kaç olursa olsun artık gelen çocuklar bizden daha donanımlı geliyor teknoloji anlamında."

\section{Öğretmen Lider Olduğunu Düşünülen Öğretmenlerin Özelliklerine İlişkin Görüşler}

Çalışma grubunda yer alan katılımcılara yöneltilen üçüncü soru "Okulunuzda öğretmen lider olduğunu düşündüğ̈̈nüz öğretmenler hangi özelliklere sahipler?', şeklindedir. Öğretmen lider olduğu düşünülen öğretmenlerin özelliklerinin araştırıldığı bu soruda katılımcıların cevapları incelendiğinde kişisel ve mesleki özellikler kategorileri belirlenmiştir. Kişisel özellikler kategorisinde öğretmenler ve yöneticiler iletişimi iyi, güvenilir ve karar vermede özgür kodlarını öne çıkarmışlardır. Bunun dışında öğretmenler öğretmen lider olduğunu düşündükleri kişilerin kişisel özelliklerine ilişkin olarak kendine güvenen kodunu ağırlıklı olarak kullanırken yöneticiler sevgi gösterme kodunu en çok kullanmışladır. Mesleki özellikler kategorisinde ise öğretmenler ve yöneticiler sosyal aktivitelerde etkin, alanında uzman ve yenilikleri takip eden kodlarında görüş birliğinde bulunmuşlardır. Bunun dışında öğretmenler öğretmen lider olduğunu düşündükleri kişilerin mesleki özellikleri arasında kişileri bir araya getiren, paylaşımcı ve veli ile işbirliği kodlarını vurgularken yöneticiler disiplinli, teknolojide yeterli ve otoriter kodlarını belirlemişlerdir. Okulundaki öğretmen liderin kararlarını vermede özerk davranan bir kişi olduğunu vurgulayan Gül “Kendi başına, birinin 
yönetmesi değil iş yapabilmesi. Nasıl diyeyim size? Başkalarının yönlendirmesi ile değil de kendi kararlarını kendileri verebilen öğretmenler. Öyle söyleyebilirim.” diyerek görüşünü belirtmiştir. Emine ise öğretmen liderin kendine güvenen birisi olduğunu, kendini sürekli geliştiren biri olduğunu, meslektaşları bir araya getiren özelliklere sahip olduğunu “Kendine özgüvenlerinin fazla olmast. Fark ettirmeden kendini izleten. Bir de lider toparlayıcı olmak zorunda. Mesela bazılarının iletişimleri birbirleriyle iyi olmayabilir ama lider onları bir araya getirip aynı amaç uğruna iş birliği yaptırabilir. Kendini geliştirecek, okuyacak. Bunu da etrafindakilere anlatacak” sözleri ile belirtmiştir. Osman ise "Bazıları iletişim becerisi anlamında öndeler. Öğrenciyle alakall kurallara uyarken sevgiyle yoğurarak despot bir tarzda değil de. Bunu yapabilen öğretmen benim için çok iyi bir öğretmen" diyerek öğretmen liderlerin farklı özelliklerine vurgu yapmıştır. Sema öğretmen liderlerin disiplinli, kendilerinden emin davranışlar sergilediklerini, yeniliklerin takipçisi olduklarını ve öğrencilerini hem akademik hem de sosyal olarak yetiştirmek amacı ile hareket ettiklerini "Kesinlikle disiplin. Şu anki okulumuzda o özelliği taşıyan 2-3 tane ögrretmen var. Bu öğretmenlerin en belirgin özelliği disiplinli olmast. Gördüğüm öğretmenler için söylüyorum, kendilerinden çok emin oldukları için, ne yaptıklarını bildikleri için kendi yollarında ilerliyorlar. Yenilikleri takip ediyorlar, uygulamaya çalışıyorlar. Sabah haber geldi, bugün yetiştirmeye çalışlyoruz. Herkes can telaş yapmaya çalışıyor, bana ne demiyor. Çocuk sadece ders açısından gelişsin demiyorlar. Sosyal olarak da gelişmelerine teşvik ediyorlar." sözleri ile belirtmiştir.

\section{Öğretmen Liderlerin Rollerine İlişkin Görüşler}

Çalışma grubunda yer alan katılımcılara yöneltilen dördüncü soru “Öğretmen liderlerin rolleri nelerdir?" şeklindedir. Öğretmen liderlerin rollerinin neler olduğunun araştırıldığı bu soruda katılımcıların cevapları incelendiğinde mesleki gelişime destek, öğretimsel liderlik, dönüşümsel liderlik, işbirliği, mentorluk, kaynak sağlayıcılık ve diğer kategorileri belirlenmiştir. Mesleki gelişime destek kategorisinde öğretmenler ve yöneticiler ortak kodlar belirlememişler ancak öğretmenler alanında uzman, özeleştiri yapabilen ve teknoloji kullanımı kodlarında, yöneticiler ise kendini geliştiren kodunda 
görüş bildirmişlerdir. Öğretimsel liderlik kategorisinde öğretmenler ve yöneticiler kategorisinde işbirlikçi kodunda ortak görüş bildirirken öğretmenler bu kategoride paylaşımcı kodunu en çok vurgulamışladır. Dönüşümsel liderlik kategorisinde öğretmenler yenilikleri takip eden ve öğrenmeye açık kodlarında görüşlerini ağırlıklandırırken yöneticiler araştırmacı kodunu vurgulamışlardır. İşbirliği kategorisinde ise veli ile iletişim halinde ve okul aile işbirliği ağlayan kodlarında öğretmenler ve yöneticiler ortak görüş ifade etmişlerdir. Bu kategoride okul idaresi ile iletişim halinde ve meslektaşlarla bir arada olma kodlarında öğretmenler görüşlerini en çok olarak vurgulamışlardır. Mentorluk kategorisinde etkileyici, hitabeti iyi, ikna yöneticiler tarafından vurgulanırken rol model olma öğretmenler tarafından belirlenen koddur. Kaynak sağlayıcılık kategorisinde kaynak getiren kodunda öğretmenler ve yöneticiler ortak görüş bildirmişler, ancak öğretmenler daha çok eldeki imkânı değerlendiren kodunda görüş bildirmişlerdir. Diğer kategorisinde ise güvenilir olma öğretmenler ve yöneticiler tarafından ortak kod olarak belirlenirken öğretmenler daha çok kendini izleten, yöneticiler ise sınıfını aktif hâle getiren, pratik çözüm kodlarında görüş verirken öğretmenler tekrara düşmeyen ve bilgiyi pratikte uygulayabilen kodlarında yoğunluklu görüş bildirmişlerdir. Tuna "Herkesin takip ettiği birisi olmak. Kendi imkânlarımla sınıfımı katarak köy okullarına yardım yapmıştım. Bir anasınıfına karton vs. hikâye kitabı, normal kaynak kitabı yardımı yapmıştım. Maddi olarak böyle şeyler olabilir. Onun haricinde hani çă̆ımız teknoloji çă̆ı. Bilimle iç içe olan her şey derslerimize yanslyabilir. FATİH Projesi kapsamında bütün sınıflarda akıllı tahta var, bazı okullarda tablet vs. dağıtıldl. Hani bunlar daha aktif bir şekilde kullanılabilir. Sadece kitap PDF açıp da oradan okumak değil aslında." şeklindeki düşüncesi ile öğretmen liderlerin mesleki gelişime destek rolüne değinmiştir. Ayrıca katılımcılardan biri “. Zümreler arasında kesinlikle ortaklık olması lazım. Mesleğinle ilgili, kendi uzmanlık alanınla ilgili bunu hayata geçirebilmek önemli. Benim için bir şeyi bilmek önemli değildir. Bildiğini uygulamak önemlidir. Liderlik de bence budur yani. Bilgileri dönüştürebilmek önemlidir. Bazı konularda da insan lider olabilir. Mesela kimi çok güzel program ayarlayabilir, kimi çok güzel plan yapabilir. İşte çoğaltılabilir. Bunları paslaşınca gerçek liderlik ortaya çıkıyor."(Ayşe) sözleri ile öğretmen liderin hem 
dönüşümsel hem de öğretimsel rolüne değinmiştir; aynı zamanda bu sözleri Ayşe öğretmenin öğretmen liderin rolleri arasında işbirliği olduğunu da ortaya koymaktadır. Veli ile işbirliğine bağlı olarak ise Ayşe görüşlerini şöyle belirtmiştir; "Veliler zaten sana destek veriyorsa sen her türlü yürüyüp gidebiliyorsun. Kaynak açısından, yine velilerden ve etraftan yarım almak gerekiyor. Mesela projeksiyon falan olmadiğ zaman mecburen velilerden destek istiyoruz." Kenan da Ayşe gibi veli işbirliğine aynı zamanda öğretmen liderin kaynak sağlayıcı rolüne de değinmiştir; şu sözleri düşüncesini desteklemektedir "Bence öğretmen aileyle etkileşimde ve aileyle bilgilerini aktarabilmeli. Kaynak bizde ciddi bir sıkıntı, bulmak da sıkıntı. Belki çevresindeki imkânları ilişkileri kullanabilir. Sosyal becerisi, sosyal ilişkisi. Belediyelerde ya da farklı iş adamları nezdinde kullanabilir." Hayriye de işbirliği rolünü vurgulamış ve “(...) Ĕğer iyi bir öğretmen, iyi bir liderse velileri de çok güzel organize ediyor. Bir defa sınıf içine allyor velileri, velilerle beraber o dersleri işliyorsunuz. Yani ben şuna karşlyım, bütün okullarda şöyle bir uygulama var; veli okula girmesin. Evet, tamam kontrol altında olsun ama veli okula girsin. Veli okulda olmalı zaten, belli sinırlar çerçevesinde sınıfta da olmall. Veli etkinlikleri yapılmall. Onlarla da beraber veli ögrenci öğretmen hani sacayă̆ı diyorlar ya bu ayak çok önemli. Ĕ̆ger öğretmen veliyle iletişim kuramıyorsa hiçbir etkinlik yolunda gitmiyor." şeklinde düşüncelerini ifade etmiştir. Kaynak sağlama rolüne ilişkin olarak ise bir katılımcı “(...) Kaynak sağlayıcılık açısından dışardan temin etmek gerekecek. Belli ki okul bu süreçte bir katkı sağlayamayacaksa bunun veli ayağı olabilir.” demiş ve kaynak temini konusunda öğretmen liderin çevre ile iletişimine değinmiştir.

\section{Öğretmen Liderlerin Okul Gelişimine Katkıları}

Çalışma grubunda yer alan katılımcılara yöneltilen beşinci soru "Liderlik davranışları gösteren öğretmenlerin okul gelişimine yönelik ne gibi katkılarl olmaktadır?" şeklindedir. Öğretmen liderlerin okul gelişimine yönelik katkılarının neler olduğunun araştırıldığı bu soruda katılımcıların cevapları incelendiğinde akademik başarı, sosyal etkinlikler, sağlıklı okul iklimi ve okul yaşam kalitesi kategorilerinde görüş bildirdikleri belirlenmiştir. Akademik başarı kategorisinde akademik başarıda yükselme ve okul 
meşruiyeti öğretmenler ve yöneticiler tarafından ortak olarak belirlenen kodlardır. Sosyal etkinlikler kategorisinde etkinliklerde aktif rol alma yine yöneticiler ve öğretmenler tarafından belirlenen kod olmuştur. Sağlıklı okul iklimi kategorisinde ise iletişim ve iklimi geliştirme çalışmaları ortak görüş bildirilen kod olmuştur. Okul yaşam kalitesi kategorisinde ise kaynak sağlama ve öğretmenlere mesleki gelişim firsatları sağlanması yöneticilerin ve öğretmenlerin hemfikir oldukları kodlar arasında yer almaktadır. Öğretmen liderlerin okula hem akademik hem sosyal etkinlikler anlamında katkıları olduğunu belirten Büşra ve Tuna sırası ile düşüncelerini şu şekilde belirtmişlerdir: "Sosyal anlamda da bir şeyler yapıllyorsa, ben sadece akademik anlamda düşünmüyorum. Çocuklar hep ders hep ders olmamall. Çocukların sosyal aktivite yapmaları gerekiyor. Okulların çocuklara farklı sosyal aktivite sunması gerekiyor. Mesela ben en son el becerileri yok çocukların. Birinci sınıfta ayakkabı tasarladık. Şu an 2.sınıfiz. Whatsapp grubumuz var ve herkes fikrini paylaşlyor. Bu yıl çocuklarla birlikte plastik iğneler aldık. İğne kullanmayı ögrreniyoruz mesela. İlerde mesela bir düğme dikeceğiz. Farklı etkinlikler olması gerekiyor. Geliştirmemiz gerekiyor kendimizi. İyi bir lider yeniliklere açık olmall."; "Hem okulu, hem de kendisini aslında. Öyle biriyseniz siz bütün veliler ve ögrenciler size gelmek ister. Öyle bir ögretmene sahipseniz parmakla gösterilir o okul. Hani gerek İlçe Millî Eğitim, il Millî Eğitim gerek veli ayağında her zaman odak noktası olursunuz, takip edilen olursunuz. O kurum istenir daha çok (...)." Muzaffer de “Okullarda, ikna yeteneklerini kullanarak çeşitli projeler üretilebilir. Bu gerek yönetimsel olarak, gerek ĕgitimsel olarak o projelerin hayata uygulanması sağlanabilir. Hayata uygulamayı sağlarken yine liderlik vasfinı kullanarak insanlardan sponsor sağlayabilir. Kısacası hayata dönüştürebilir. Akademik açıdan bir kere çocukların eğitiminde önemli bir rol oynar. Başlattı̆̆ hareketle ögretmenlerin motivasyonuyla ögretmenlerin kendilerini geliştirip ileride daha etkili ĕgitim ve ĕger yöneticilik vasfinda varsa yöneticilik birimlerinde daha etkili olmasını sağlar diye düşünüyorum." diyerek öğretmen liderlerin katkılarına değinmiştir. 


\section{Öğretmen Liderlerin Karşılaştıkları Engellere İlişkin Görüş̧ler}

Çalışma grubunda yer alan katılımcılara yöneltilen altıncı soru "Okulunuzda ögretmenlerin liderlik özelliği gösterebilmeleri konusunda karşılaştıkları engeller neler olabilir?" şeklindedir. Öğretmenlerin öğretmen lider olabilmelerinin önündeki engellerin araştırıldığı bu soruya katılımcıların verdiği cevaplar incelendiğinde bürokratik engeller, okul yönetiminin ve meslektaşların engelleri ve diğer kategorileri belirlenmiştir. Bürokratik engeller kategorisinde okul yöneticileri ve öğretmenler mevzuat ve müfredat takibi, öğretmen yetkilerinin kısıtlanması ve iş yükü konularında ortak görüş dile getirmişlerdir. Okul yönetimi ve meslektaş engelleri kategorisinde yöneticinin kendisi ve meslektaşların yeniliğe açık olmamaları ortak kodları oluştururken, yöneticiler yöneticilerin riskten kaçmalarını, öğretmenler ise meslektaş kıskançlığını en çok vurgulamışlardır. Diğer kategorisinde kaynak yetersizliği, okul çevresinin sosyoekonomik düzeyi yöneticiler ve öğretmenler tarafından belirlenmiştir. Bürokratik engellere ilişkin olarak Muzaffer "Bunlar genelde devlet politikalarından kaynaklanabilir (...) Şöyle söyleyeyim; yapmak istediğimiz şeylerin her zaman önüne geçiş var ve öğretmenin ögrretmenlik vasıflarından çıkarılması, yetkilerinin gittikçe kısıtlanması. İş yükünün artması da bir etken olabilir.” demiştir. Osman da Muzaffer’in düşüncelerine "Mevzuat anlamında bazı engeller oluyor. Mesela kaynak kitap kullanımı en basit. Geziyle alakalı da üst birimler çok sorumluluk almıyor. Önceden izin alınırdl, onay alınırdı. Şimdi bu sorumluluk okula indirgenmiş durumda. Bu da öğretmenler de baskı unsuru oluyor. Dışarda bir geziye gidilecekse gibi. Yine maddi anlamda kaynak yetersizliği. En büyük sorun o (...) Günümüz yöneticilerinde şunu görüyoruz; minimum risk, mevcudu koruyalım, başımız ağrımasın. O yüzden kimseye yetki de vermeyelim. Kimsenin gelişimini destekleyecek hamlelerde bulunmayalım mantığ var. Ben bunu gözlemliyorum." diyerek katılmaktadır. Yöneticiden kaynaklanan engellere ilişkin Zeynep görüşünü “(...) İdarecinin katı görüşü olabilir, hani daha yenilikçi olmayabilir -ki devlet okullarında bu daha fazladır- hani burada öyle bir şey yok çünkü amaç çocuk olduğu için. Eminim orada da amaç çocuk ama bir şekilde katı bir şey var yani." şeklinde belirtirken Gül "Yani yönetim engelliyor. Şu anki okulumda da eski çalıştı̆̆ım okulda da bu sorunlarla karşılaştım dediğim gibi. Yönetici izin vermediği sürece her 
türlü. Çevre de etkiler. Meslektaşlar ve veliler arasında da olur." şeklinde belirtmişlerdir.

\section{Öğretmen Liderliğini Geliştirmeye Yönelik Görüşler}

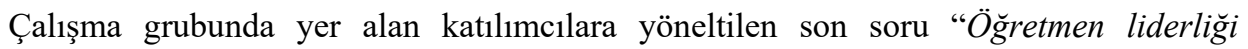
geliştirme konusunda sizin önerileriniz nelerdir?" şeklindedir. Öğretmen liderliğini geliştirmeye yönelik katılımcıların önerilerinin araştırıldığı bu soruda katılımcılar yönetici açısından, öğretmen açısından ve diğer kategorilerinde görüş bildirmişlerdir. Yönetici açısından kategorisinde öğretmen motivasyonu öğretmenler ve yöneticiler tarafindan en çok vurgulanan kod olmuştur. $\mathrm{Bu}$ kategoride öğretmenlerin en çok vurguladığı diğer kodlar ise İl/İlçe Millî Eğitim Müdürlüğü desteği ve yetki devri olmuştur. Öğretmen açısından kategorisinde öğretmenler iç motivasyon, başarı hazzı vurgulanırken yöneticiler öğretmenin kendini geliştirmesi kodunda en çok görüş bildirmişlerdir. Diğer kategorisinde ise eğitici seminerler düzenlenmesi yöneticiler ve öğretmenlerin en çok vurguladığı kod olmuştur. Katılımcıların öğretmen liderliğini geliştirmeye yönelik önerilerinden bazıları şu şekildedir; "Bir de öğretmenin içindeki şeyi teşvik etmek lazım, cesaretlendirmek lazım. Tabiri caizse gaza getirilebilir, öyle söyleyeyim. Güdülemek gibi.”(Gül); “Ket vurulmamall. Yöneticiler tarafindan ket vurulmamall. Tam tersi yöneticiler, bir yenilik yapmak istediğinde ya da herhangi bir fikri olduğunda öğretmene destek olmalı. Ayrıca tabii ki İl Millî Eğitim de, İlçe Millî Eğitim de ögrretmene destek olmall. Ben daha önce de söyledim. Ben şunu söyledim; bizim okulda zekâ oyunları odası olması gerektiğini düşünüyorum. Ama göz ardı edildi yapılmadl, olabilir. Belli bir süre sonra sadece kendi sınıfimla yapıyorum." (Büşra); “Bir; idare destek olacak. Önünü açacak ya da yaptığı şeyler görünür kılınacak. Ya da takdir edilecek, en önemlisi bu. Çalışma ortamı rahatlatılabilir, sınıf sayıları ona göre düzenlenebilir." (Damla); "Aslında insanlara ben değil de biz bilincini aşılamaya çalıştığımızda ve hani yere çöp atma diyoruz mesela en ufă̆l. Onu kendisi için değil de gelecek nesil içinde birazcık düşünerek bir bilinç oluşturabilsek. Mesela şu an popüler olan ne var kaynakların tükenmesi. Aslında hepimiz o bilinçte olsak. Yani insanların bilinçlenmesiyle ilgili olduğunu düşünüyorum.”(Tuna); “Öğretmenlere, kendini 
geliştirebilecek kurslar, sertifika programları açılabilir yani bunlara yönlendirilebilir. Aile bilgilendirme eğitimlerine ă̆ırlık verilebilir. Kurslar artırllabilir, yüksek lisans, doktora zorunlu olabilir. Öğretmen üzerindeki o baskl, idarenin milli eğitimin baskısı azaltılabilir. Öğretmene biraz daha alan açılabilir." (Kenan).

\section{Okul Yöneticilerinin Öğretmen Liderlere Katkılarına İlişkin Görüşler}

Çalışma grubunda yer alan "Bir okul yöneticisi olarak öğretmenlerin liderlik davranışı göstermeleri konusunda sizin ne gibi katkılarınız bulunmaktadır?” şeklindeki soru ise sadece okul yöneticilerine yöneltilmiştir. Okul yöneticilerinin öğretmen lider olunmasına ilişkin katkılarının araştırıldığı bu soruda okul içi ve okul dışı olmak üzere iki kategori belirlenmiştir. Okul içi kategorisinde önderlik etme ve motivasyon en çok vurgulanırken okul dişı kategorisinde öğretmenlere eğitimler verilmesi kodu en çok vurgulanmıştır. Okul yöneticilerinden Muzaffer öğretmen liderlere katkı bağlamında kendisi yetki devri yaptığını, öğretmenleri motive etmeye çalıştığını ifade etmiştir; "Yetki devrinde şudur; bir komisyon kuruyorsam o komisyonun başında ben varsam ben sadece orada kontrolör olarak görev yapmayı tercih edip, genelde öğretmenleri motive edip yetki vererek onların kendilerini farklı çalışmalara sokmaya.....”; Osman ise "Bence günümüzde liyakat sistemi olmadı̆̆ için maalesef okul müdürlerinde liderlik vasfi çok yok. Kimse yetkisini devretmiyor. Neden? Çünkü kimse önüme geçmesin. Ben her şeyi göze alarak onlara yol açıyorum. .....Ben sadece kapıyı araladım. Ama kapıyı açan sizsiniz. Ve ben yapmış olduğum bütün konuşmalarımda, verdiğim röportajlarda ilçeye falan kesinlikle kendi adımı kullanmadım. Yapılan çalışmalar ögretmenlerimindir." şeklinde öğretmenlerini motive ederek, onlarla birlikte takım halinde çalışarak, onların başarılı olmaları için esneklik yaratıp etkili ortam sunarak katkı sağladığını belirtmiştir.

\section{TARTIŞMA ve SONUÇ}

Yönetici ve öğretmenler öğretmen liderliğinin anlamına ilişkin görüşlerini kişisel özellikler ve mesleki özellikler olmak üzere iki kategoride değerlendirmişlerdir. Liderlik özelliklerine sahip öğretmenlerin sahip olması gereken kişisel özelliklerin 
arasında öğrenciye sevgi vermesi, girişimci ve araştırmacı olması, risk alması ve ikna edebilmesi; mesleki özellikler arasında ise rehberlik etmesi, disiplinli, alanında uzman, yenilikleri takip etmesi bulunmaktadır. Katılımcıların öğretmen liderliği açıklamada genellikle olumlu kavramlar kullandıkları göze çarpmaktadır. Araştırmanın bu bulgusu Savaş (2019) ve Balyer'in (2016) yapmış oldukları çalışmaların bulguları ile benzerlik göstermektedir. Savaş (2019) tarafından okul müdürlerinin görüşlerine göre öğretmen liderliğinin ne anlama geldiğini belirlemeye yönelik yapılan çalışmada öğretmen liderliğin anlamı diğer öğretmenlere ve öğrencilere rehberlik etmek, işbirliği içinde çalışmak girişimci ve katılımcı bir kişilik yapısına sahip olmak ve diğerlerini etkileyip onlara rol model olmak olarak belirtilmiştir. Balyer (2016) öğretmenlerin öğretmen liderliği algısını incelediği çalışmasında öğretmen liderliğini okulda etkin olmak, meslektaşlarla yardımlaşmak, deneyimleri aktarmak, okul-aile işbirliği sağlamak, çevreyi etkilemek ve değişim sürecine daima hazır olmak şeklinde ifade etmiştir. Bu bağlamda birinci alt problem kapsamında ortaya çıkan sonuçlarla alanyazında öğretmen liderliğinin anlamı ile ilgili yapılan araştırmaların tutarlı olduğu görülmektedir.

Yönetici ve öğretmenler öğretmen liderlerin sahip olması gereken özellikleri teknik, kişisel ve kavramsal özellik olmak üzere üç kategoride değerlendirmişlerdir. Teknik özellikler arasında en fazla belirtilen öğretmen liderlerin sahip olduğu özellikler iletişimin iyi olması, işbirlikçi, paylaşımcı ve yenilikleri takip etmesi iken; kişisel özellikler güvenilir olması, ikna kabiliyeti olması, disiplinli olması, risk alabilmesi ve sözünde durması olarak belirlenmiştir. Kavramsal özellikler arasında ise alanında uzman olması, çağa ayak uydurması ve örnek olması en çok belirtilen özelliklerdir. Katılımcıların tüm bu görüşlerinin ortak sonucu olarak öğretmen liderlerin okulda birleştirici ve yenilikçi özelliğe sahip olması gerektiği sonucu çıkarılmıştır. Koşar'ın (2018) öğretmenlerin öğretmen liderliği konusundaki görüşlerini inceleyen çalışması ve Savaş’ın (2019) çalışması öğretmen liderlerin sahip olması gereken özellikler konusunda bu çalışmanın bulguları ile benzerlik göstermektedir. Öğretmen liderliğe sahip öğretmenlerin sahip olması gereken özellikler arasında güvenilir olma, yeniliğe ve dönüşüme açık olma, diğerlerini etkileme, paylaşımcı ve işbirlikçi olma ve risk almanın bulunduğu saptanmıştır. Zülfizade (2020) de çalışmasında lider öğretmenlerin sahip 
olması gereken özellikler arasında iyi iletişim kurma özelliği, mesleki yeterlilik, örnek olma, yenilikleri takip etme, hitabetinin iyi olması, yardımcı olma, problem çözme, güven sağlama, kurum kültürüne sahip olmanın yer aldığı sonucuna ulaşmıştır. Alanyazında yapılan bu araştırmalar ikinci alt problem kapsamında elde edilen sonuçları destekler niteliktedir.

Okullarda öğretmen lider olduğu düşünülen öğretmenlerin özellikleri kişisel özellikler ve mesleki özellikler olmak üzere iki kategoride toplanmıştır. Kişisel özellik olarak en çok belirtilen özellikler iletişimin iyi olması, karar vermede özgür olma, güvenilir olma ve kendine güvenmedir. Mesleki özellikler olarak ise alanında uzman ve paylaşımcı olma, sosyal aktivitelerde ve projelerde etkin olma ve kişileri bir araya getirebilme ortaya konmuştur. Sonuç olarak öğretmen liderlerin okulu ileri taşıyacak olumlu özelliklere sahip kişiler olduğu söylenebilir. Beycioğlu'nun (2009) ilköğretim okullarında öğretmenlerin sergiledikleri liderlik rollerini incelemek amaciyla yaptı̆̆ araştırmada öğretmen liderlerin işbirliği içinde projelerde faaliyet gösterdiği ve meslektaşlarla işbirliği içinde olduğunu saptamıştır. Harrison ve Killion (2007) da öğretmen liderlerin sahip oldukları rolleri içeren çalışmasında öğretmen liderlerin hem kendilerinin hem de meslektaşlarının mesleki gelişimlerine katkı sağladığı bilgisine ulaşmıştır. Zülfizade (2020) yapmış olduğu araştırmada lider öğretmenlerin özellikleri arasında iyi iletişim kurma, yardımcı olma, aktif olma, problem çözme yenilikleri takip etme, sosyal olma, öğrendiklerini paylaşma, fikirlerini açık ifade etme, başkalarını yönlendirme, mesleki yeterlilik, örnek olma, inisiyatif alma olduğunu vurgulamıştır. Bu çalışma sonuçları ve alanyazından elde edilen sonuçlar birlikte değerlendirildiğinde okullarda liderlik davranışları sergileyen öğretmenlerin sosyal etkinlik ve projelerde aktif rol oynadığı, işbirliği içinde mesleki gelişime önem verdikleri sonucu çıkarılabilir.

Okul yöneticileri ve öğretmenlerin öğretmen liderlerin rollerine ilişkin görüşleri, mesleki gelişime destek, öğretimsel liderlik, dönüşümsel liderlik, işbirliği, mentorluk, kaynak sağlayıcılık ve diğer olmak üzere yedi kategoride incelenmektedir. Mesleki gelişime destek kategorisinde alanında uzman olma ve kendini geliştirebilme, ögretimsel liderlik rolleri için paylaşımcı ve işbirlikçi olma kavramları belirtilmektedir. 
Dönüşümsel liderlik için ise en fazla belirtilen özellikler yenilikleri takip etme ve öğrenmeye açık olma; işbirliği kategorisi için de veliyle iletişim halinde olma ve okulaile işbirliği sağlama yer almaktadır. Mentorlük için ikna etme, rol model olma özellikleri belirtilirken, kaynak sağlayıcılık kategorisinde kaynak sağlama en fazla belirtilen özelliklerdendir. Son kategori olan diğer kategorisinde ise en fazla belirtilen özellikler kendini izletme ve güvenilir olma özellikleridir. Bu çalışma, Millwater ve Ehrich'in (2009), öğretmen eğitimi ile öğretmen liderliğini temel alan çalışmasının öğretmen liderlerin grubu etkileme ve sürükleme, aynı zamanda mentorlük rolü ile deneyimli öğretmenlerin göreve yeni başlayan öğretmenlerin mesleki gelişimine katk1 sağlama gibi rolleri olduğu sonucuyla benzerlik göstermektedir. Koşar (2018) ve Balyer (2016) yapmış oldukları çalışmalardan öğretmen liderliği rolleri arasında yeniliğe açık ve dönüşümcü olma, öğretimsel anlamda da liderlik yapabilme, işbirliği içinde çalışmanın var olduğu sonucunu elde etmişlerdir. Koşar (2018) bunlara ek olarak kaynak sağlayıcılığın da öğretmen liderliği rollerinden biri olduğunu belirtmiştir. $\mathrm{Bu}$ bağlamda çalışmadan elde edilen öğretmen liderliği rolleri sonuçları ile alanyazında belirtilen öğretmen liderliği rolleri birbiri ile tutarlıdır.

Okul yöneticileri ve öğretmenlerin liderlik davranışları gösteren öğretmenlerin okul gelişimine yönelik katkılarına ilişkin görüşleri dört kategori altında incelenmektedir. Yönetici ve öğretmenlere göre öğretmen liderliği okullarda akademik başarının olumlu anlamda gelişmesine ve okulların isimlerinin duyulmasına katkı sağlar. İkinci kategori olan sosyal etkinlikler ile ilgili en çok belirtilen görüş sosyal etkinlikler ve projelerde yer almaktır. Sağlıklı bir okul iklimi olan üçüncü kategoride en fazla belirtilen görüşler örgüt iklimini geliştirme, sağlıklı iletişim yaratma, paylaşım ve işbirliğini iletişimi güçlendirmesidir. Son kategori olan okul yaşam kalitesini artırmak için yaygın olan görüşler arasında kaynak sağlamanın kolaylaşması ve öğretmenlere mesleki gelişim fırsatlarının sunulması yer almaktadır. Sonuç olarak katılımcılar okullarında öğretmen liderlerin bulunmasının okullarının imajının daha çok içselleştirilmesine ve güçlendirilmesine, örgüt ikliminin daha sağlıklı olmasına böylelikle öğretmenler arası paylaşımların artmasına etki edeceğine ilişkin görüşler sunmuşlardır. Araştırmanın bu bulgusu Araşkal ve Kılınç’ın (2019) yapmış oldukları araştırma bulgusu ile kısmen 
benzerlik göstermektedir. Söz konusu araştırmada öğretmen liderlerin öğretimi geliştirme noktasında meslektaşları ile işbirliği yapmalarının gerekli olduğu öğretimi geliştirme temasında ortaya çıkmıştır. Benzer şekilde, Leithwood (2003) tarafından öğretmen liderliğinin öğrenci ve okulun gelişimi ve etkisi üzerine yürütülen ve Harris ve Muijs (2005) tarafından öğretmen liderliği sayesinde okulların gelişimi üzerine yürütülen çalışmaların sonuçları öğretmen liderliğinin okullardaki akademik başarının artmasına ve öğretmenlerin işbirliği içinde çalışarak birbirlerinin mesleki gelişimlerine destek olmalarına katkı sağladığı sonucunu ortaya koymuştur. Bu çalışma; Yiğit, Doğan ve Uğurlu'nun (2013) öğretmenlerin öğretmen liderliğine ilişkin görüşlerini ortaya koymak için yürüttükleri araştırmanın ve Harris'in (2005) öğretmen liderliğinin iyi hissetmenin ötesindeki fonksiyonlarına ilişkin yürüttüğü çalışmaların sonucunda elde edilen öğretmen liderliğinin okuldaki örgüt iklimini olumlu yönde etkileme ve işbirliği ve güven ortamı oluşturma sonucuyla benzerlik göstermektedir. Öğretmen liderliğin okulların gelişmesine en büyük katkısı olarak okul akademik başarısının artması ve okul örgüt ikliminin işbirliğini esas alması kabul edilebilir.

Yönetici ve öğretmenlerin okullarda öğretmenlerin liderlik özelliği gösterebilmeleri konusunda karşılaştıkları engellere ilişkin görüşler, bürokratik engeller, okul yönetiminin ve meslektaşların oluşturduğu engeller ve diğer olmak üzere üç kategori altında belirtilmektedir. Bürokratik engeller arasında mevzuat ve müfredat takip zorunluluğu ve öğretmen yetkilerinin kısıtlanması en fazla belirtilen görüşlerdir. İkinci kategori olan okul yönetiminin ve meslektaşların oluşturduğu engeller kategorisinde en çok ifade edilen engeller, yönetici engeli, meslektaşlar arası kıskaçlık ve meslektaşların yeniliğge açık olmaması olarak belirtilmektedir. Son olarak diğer kategorisinde veli engeli, kaynak yetersizliği ve okul çevresinin sosyo-ekonomik durumu en fazla belirtilen görüşlerdir. Savaş’ın (2019) yürüttüğü çalışmadan öğretmenlerin öğretmen liderliği özellikleri gösterebilmeleri konusunda karşılaştıkları engellere ilişkin öğretmenlerin formel görevlerinin ardından yeterli zamanın kalmaması ve okulların fiziki şartlarının elverişsizliği sonucu bu çalışmadan elde edilen sonuçlarla kısmen benzerlik göstermektedir. Can’ın (2006a) öğretmen liderliği ve engellerini konu alan çalışmasından elde ettiği sonuçlar arasında okul yönetimlerinin öğretmenlerin liderlik 
davranışlarına karşı olumsuz tutumları ve diğer öğretmenler tarafından dışlanma ve onlardan tepki görme bulunmaktadır. Zülfizade'nin (2020) araştırmasında öğretmenlerin liderlik rolü üstlenmesindeki engeller ücret yetersizliği ve zaman yetersizliğidir. Ayrıca sorumluluk almak, yönetmelikler, tükenmişlik, ailevi sorunlar, mesleki yetersizlik, motivasyon eksikliği, sorunlu iletişim ortaya çıkan diğer engellerdendir. Buradan hareketle yönetici ve öğretmenlerin belirtmiş oldukları okullarda görev yapan öğretmenlerin liderlik davranışları göstermesi konusunda karşılaştıkları engeller ile alanyazından elde edilen sonuçların benzerlik gösterdiği görülmektedir. Araştırma sonucuna dayalı olarak öğretmenlerin yeni yöntem kullanmalarına olanak sağlayıcı, bürokratik hantallığın olmadığı, işbirliğine ve paylaşıma destek sağlayıcı bir iklimin öğretmen liderliğinin önemli unsurlarından olduğu söylenebilir.

Okul yöneticileri ve öğretmenlerin öğretmen liderliğini geliştirme konusuna ilişkin görüşleri üç kategori altında incelenmektedir. Yönetim açısından öğretmen liderliğini geliştirecek olan görüşlerden bazıları öğretmenlerin motive edilmesi, yönetici desteğinin sağlanması ve öğretmeni takdir etme ve ödüllendirmedir. Öğretmen açısından öğretmen liderliğinin gelişimine katkı sağlayacak davranışlara öğretmenin daha cesur olması, bireysel düşünmenin azaltılması ve öğretmenin kendini geliştirmesi görüşleri belirtilmektedir. Diğer isimli son kategoride yer alan görüşlerden bazıları ise eğitici seminerler düzenlenmesi, öğretmene daha fazla özgür alan tanınması ve çalışma ortamının iyileştirilmesidir. Beycioğlu ve Aslan (2012) tarafından öğretmen liderliğine ilişkin öğretmen ve yönetici görüşlerini incelemek için yürütülen çalışmadan ve Can'ın (2006b) yürüttüğü çalışmadan öğretmen liderliğini geliştirmek için yönetici ve öğretmen görüşlerine ilişkin elde edilen okul yönetiminin öğretmenlere destek olması ve onları karar alma sürecine dâhil etmeleri, yenilikçi ve güven veren bir okul ortamının oluşturulması ve öğretmen geliştirme programlarının geliştirilip zenginleştirilmesi sonuçları bu araştırmadan elde edilen sonuçların bir kısmıyla benzerlik göstermektedir. Öğretmenlere eğitim aldıkları dönemden itibaren öğretmen liderliğini tanıtılması ve öğretmenlerin çalışma ortamlarında daha özerk olması öğretmen liderliğinin uygulanabilirliği açısından önemlidir. 
Okul yöneticilerinin bir okul yöneticisi olarak öğretmenlerin liderlik davranışı göstermeleri konusundaki katkılarına ilişkin görüşleri okul içi ve okul dışı olmak üzere iki kategoride incelenmektedir. Okul içinde bulunulabilecek katkılar için öğretmeni motive etme ve önderlik etme en çok belirtilen görüşler arasında yer alırken okul dışında yapılabilecek eylemler için öğretmenlere eğitim verilmesi ve öğretmen liderlerin birbirleriyle iletişim kurması görüşleri yer almaktadır. $\mathrm{Bu}$ çalışmanın sonucu ile Savaş’ın (2019) yürüttüğü çalışmasından elde ettiği sonuçlar arasındaki benzerlik okul yöneticilerinin öğretmenlerin liderlik davranışları gösterme konusundaki gösterdikleri katkılar arasında yöneticilerin öğretmenlere rehber olduğu, öğretmenlerin mesleki gelişimleri konusunda onlara kolaylık sağladığı ve öğretmenleri liderlik özellikleri göstermeleri konusunda motive ettiği ve cesaretlendirdiği bilgisidir.

Öğretmen liderlerin hem sınıf içinde hem de okulun genelinde örgütsel vatandaşlık davranışı gösterebilen, öğrencilerin öğrenmeleri, sosyal ve akademik gelişimlerini sağlama konusunda öncülük eden, meslektaşları ile kişisel ve mesleki gelişim konusunda paylaşımlarda bulunan, çevresini etkileyebilen kişiler oldukları görülmektedir. Önemli olan öğretmenlerin hem sınıf içerisinde hem de okulda liderliği nasıl sergiledikleri, hangi özellik ve rolleri ile liderlik davranışlarını yerine getirdikleri, liderlik becerilerini nasıl geliştirdikleridir. Bu bağlamda öğretmen liderler kendilerini sürekli yenilemeli, değişime açık olmalı ve iletişim becerilerini geliştirme konusuna önem vermelidirler. Bu bağlamda kişisel ve mesleki seminerlere, etkili iletişim, beden dili kullanımı gibi çeşitli eğitimlere, konferanslara katılabilirler. Aynı zamanda öğretmen liderlerin alanlarına ilişkin ulusal ve uluslararası alanyazını takip ederek yeni uygulama, kuram ve görüşleri anlayarak kendi çalışmalarına, eğitsel faaliyetlerine destekleyici uygulamalar geliştirmeleri önemlidir. Unutulmaması gereken başka önemli bir husus da okul yöneticilerinin öğretmenlerin liderlik davranışlarını fark etmelerini ve geliştirmelerine olanak sağlayan ortamlar hazırlamalarıdır; öğretmenlere liderlik özelliklerini ortaya çıkarmaları için fırsatlar tanınabilir bu nedenle okul müdürleri öğretmen liderliğini destekleyici tutum sergilemeli, işbirliği, karara katılım gibi konulara önem vermelidir. Aynı zamanda farklı okullardaki lider öğretmenler arası işbirliği güçlendirilerek bir iletişim ağı oluşturulabilir. Bu araştırmanın sonuçlarından 
biri olan öğretmen liderliğini engelleyen unsurlardan biri olan bürokratik engeller göz önünde bulundurulduğunda öğretmenlerin iş yükleri konusunda planlamalar geniş bir çerçevede ele alınabilir, öğretmen liderliğinin engelleri, bu engellere ilişkin çözüm önerilerini derinlemesine inceleyen çalışmalara yer verilebilir 


\section{KAYNAKLAR}

Araşkal, S. ve Kılınç, A. Ç. (2019). Öğretmen liderliğini etkileyen faktörlerin incelenmesi: Nitel bir araştırma. Kuram ve Uygulamada Eğitim Yönetimi Dergisi, 25(3), 419-468.

Balyer, A. (2016). Öğretmen liderler: Öğretmen algıları üzerine nitel bir araştırma. Elemantary Education Online, 15(2), 391-407. http://dx.doi.org/10.17051/io.2016.81764

Beycioğlu, K. (2009). Illköğretim okullarında öğretmenlerin sergiledikleri liderlik rollerine ilişkin bir değerlendirme (Hatay İli Örneği). (Doktora tezi). İnönü Üniversitesi, Sosyal Bilimler Enstitüsü, Malatya.

Beycioğlu, K. ve Aslan, B. (2012). Öğretmen ve yöneticilerin öğretmen liderliğine ilişkin görüşleri: Bir karma yöntem çalışması. Kuram ve Uygulamada Eğitim Yönetimi Dergisi, 18(2), 191-223.

Burgess, J., \& Bates, D. (2010). Other duties as assigned: Tips, tools and techniques for expert teacher leadership, Alexandria: ASCD.

Can, N. (2006a). Öğretmen liderliği ve engelleri. Sosyal Bilimler Araşstırmaları Dergisi. $2,137-161$.

Can, N. (2006b). Öğretmen liderliğinin geliştirilmesinde müdürün rol ve stratejileri. Erciyes Üniversitesi Sosyal Bilimler Enstitüsü Dergisi, 21(2), 349-363.

Can, N. (2007). Öğretmen liderliği becerileri ve bu becerilerin gerçekleştirilme düzeyi. Erciyes Üniversitesi Sosyal Bilimler Enstitüsü Dergisi, 22(1), 263-288.

Can N. (2009). Öğretmenlerin sınıfta ve okulda liderlik davranışları, Gaziantep Üniversitesi Sosyal Bilimler Dergisi, 8(2), 385-399.

Can, N. (2014). Öğretmen liderliği. (4. Baskı). Ankara: Pegem Akademi.

Conley, D. T. (1993). Roadmap to restructuring: Policies, practices and the emerging visions of schooling. Retrieved from https://files.eric.ed.gov/fulltext/ED359593.pdf

Crowther, F. A., Ferguson, M., \& Hann, L. (2009). Developing teacher leaders: how teacher leadership enhances school success, 2nd ed. Corwin (Sage), Thousand Oaks, CA. United States. ISBN 978-1-4129-6374-9

Çelik, V. (2008). Sinıf yönetimi. Ankara: Nobel.

Elmas, G. (2018). Ortaokul öğretmenlerinin öğretmen liderliği davranışlarına ilişkin görüşlerinin incelenmesi. (Yayımlanmamış yüksek lisans tezi). Gaziantep Üniversitesi Eğitim Bilimleri Enstitüsü, Gaziantep. 
Frost. D., \& Harris, A. (2003). Teacher leadership: Towards a research agenda. Cambridge Journal of Education, 33(3), 479-498. https://doi.org/10.1080/0305764032000122078

Günkör, C. (2017). Eğitim ve kalkınma ilişkisinin incelenmesi. Uluslararası Sosyal Bilimler Ĕ̈itimi Dergisi, 3(1), 14-32.

Harris, A. (2002). Effective leadership in schools facing challenging context. School Leadership and Management, 22(1), 15-26. https://doi.org/10.1080/13632430220143024a

Harris, A. (2003). Teacher leadership as distributed leadership: Heresy, fantasy or possibility? School Leadership \& Management, 23(3), 313-324. https://doi.org/10.1080/1363243032000112801

Harris, A. \& Lambert, L. (2003). Building leadership capacity for school improvement. Philadelphia: Open University.

Harris, A., \& Muijs, D. (2005). Improving schools through teacher leadership. London, UK:McGraw-Hill Education.

Harrison, C., \& Killion, J. (2007). Ten roles for teacher leaders. Educational Leadership, 65(1), 74-77.

Işı, M. ve Bahat, İ. (2018). Okul yöneticilerinin öğretmen liderleri algilari üzerine nitel bir araştırma. Uluslararası Eğitim Bilimleri Dergisi, 5(14), 31-56.

Katzenmeyer, M., \& Moller, G. (2013). Uyuyan devi uyandırmak, ögretmen liderler yetiştirmek (Çev. Ed. S. Özdemir). Ankara: Nobel.

Kılınç, A. Ç. ve Recepoğlu, E. (2013). Ortaöğretim okulu öğretmenlerinin öğretmen liderliğine ilişkin algı ve beklentileri. Kalem Eğitim ve İnsan Bilimleri Dergisi, $3(2), 175-215$.

Kılınç, A. Ç. (2014). Examining the relationship between teacher leadership and school climate. Educational Sciences: Theory and Practice, 14(5), 1729-1742.

Kılınç, A. Ç. (2016). Çağdaş liderlik yaklaşımları: öğretim liderliği, öğretmen liderliği, dağıtımcı liderlik. N. Güçlü ve S. Koşar (Ed.), Eğitim yönetiminde liderlik: teori, araştırma ve uygulama (3. baskı) içinde (s. 69 -89). Ankara: Pegem Akademi.

Koşar, D., Er, E., Kılınç, A. Ç. ve Koşar, S. (2017). Öğretmen liderliğine ilişkin yapılan çalışmaların incelenmesi: Bir içerik analizi çalışması. Inönü Üniversitesi Eğitim Bilimleri Enstitüsü Dergisi, 4(7), 29-46.

Koşar, D. (2018). Examining the views of prospective teachers on teacher leadership. European Journal of Education Studies, 4(3), 157-173. DOİ:10.5281/zenodo.1196645

Lambert, L. (1998). Building leadership capacity in schools. Alexandria, Virginia: Association for Supervision and Curriculum Development. 
Leithwood, K. (2003). Teacher leadership: Its nature, development, and impact on schools and students. In M. Brundrett, N. Burton, R. Smith (Eds.), Leadership in education (pp. 103-117). Thousand Oaks, CA: Sage.

Mangin, M. M. (2005). Distributed leadership and the culture of schools: Teacher leaders' strategies for gaining access to classrooms. Journal of School Leadership, 15(4), 456-484. https://doi.org/10.1177/105268460501500405

Mayo, K. E. (2002). Teacher leadership: The master teacher model. Management in Education, 16(3), 29-33. https://doi.org/10.1177/08920206020160030701

Millwater, J., \& Ehrich, L. C. (2009). Teacher leadership: Interns crossing to the domain of higher professional learning with mentors? Refereed paper presented at 'Teacher education crossing borders: Cultures, contexts, communities and curriculum' the annual conference of the Australian Teacher Education Association (ATEA), Albury, 28 June -1 July. Retrieved from https://files.eric.ed.gov/fulltext/ED524608.pdf

Murphy, J. (2005). Connecting teacher leadership and school improvement. Thousand Oaks, California: Corwin Press.

Özdemir, S., \& Kılınç, A. Ç. (2015). Teacher leadership: A conceptual analysis. In K. Beycioğlu ve P. Pashiardis (Eds.), Multidimensional perspectives on principal leadership effectiveness (pp. 257-282). Hershey, PA: IGI Global.

Özden, Y. (2005). Eğitimde yeni değerler. Ankara: Pegem Akademi.

Savaş, G. (2019). Okul müdürlerinin görüşlerine göre öğretmen liderliği: Nitel bir araştırma. Uluslararası Liderlik Çalışmaları Dergisi: Kuram ve Uygulama, 2(3), 207-222.

Silva, D. Y., Gimbert, B., \& Nolan, J. (2000). Sliding the doors: Locking and unlocking possibilities for teacher leadership. Teachers College Record, 102(4), 779-804. DOI: $10.1111 / 0161-4681.00077$

T.C. Milli Eğitim Bakanlığı. (2017). Öğretmen Strateji Belgesi. http://oygm.meb.gov.tr/meb_iys_dosyalar/2017_07/26174415_Strateji_Belgesi_ RG-Ylan-_26.07.2017.pdf adresinden erişilmiştir.

T. C. Milli Eğitim Bakanlığı. (2018). 2023 Eğitim Vizyonu. http://2023vizyonu.meb.gov.tr/ adresinden erişilmiştir.

Uğurlu, C. T. ve Yiğit, Y. (2014). Öğretmenlerin öğretmen liderliği algılarının örgütsel vatandaşlık davranışlarına etkisi. Buca Eğitim Fakültesi Dergisi, 38, 36-56.

Ünver, G., Talu-Bümen, N. ve Başbay, M. (2010). Ortaöğretim alan öğretmenliği tezsiz yüksek lisans derslerine öğretim elemanı bakışı: Ege Üniversitesi örneği. Eğitim ve Bilim Dergisi, 155(35), 63-77.

Yıldırım, A. ve Şimşek, H. (2006). Sosyal bilimlerde nitel araştırma yöntemleri. Ankara: Seçkin. 
Yiğit, Y., Doğan, S. ve Uğurlu, C. T. (2013). Öğretmenlerin öğretmen liderliği davranışlarına ilişkin görüşleri. Cumhuriyet Uluslararası Eğitim Dergisi, 2(2), 93-105.

Zülfizade, T. (2020). Profesyonel bir kimlik olarak öğretmen liderliği. (Yayımlanmamış yüksek lisans tezi). Bursa Uludağ Üniversitesi, Eğitim Bilimleri Enstitüsü, Bursa.

\section{ORCID}

Özge AYVALI (D) http://orcid.org/0000-0002-4585-1111

Didem KOŞAR (B) http://orcid.org/0000-0003-4959-1094 


\section{SUMMARY}

\section{Introduction}

The aim of this study is to examine the views of school administrators and teachers on teacher leadership. In line with this main purpose, the following sub-goals were sought; According to the views of school administrators and teachers, (i) what is the meaning of teacher leadership ?, (ii) what characteristics should teacher leaders have?, (iii) what are the characteristics of teachers who are thought to be teacher leaders in schools?, (iv) what are the roles of teacher leaders?, (v) what kind of contributions do teachers with leadership behaviors make for school improvement?, (vi) what are the obstacles teachers face in terms of leadership characteristics in schools?, (vii) what are the suggestions for supporting teacher leadership ?, and finally (viii) what are the contributions of school administrators to teachers' leadership behaviors?

\section{Methodology}

Qualitative data collection techniques and phenomenology design were used in this study. This research is in phenomenology design as it is conducted by using interview technique with administrators and teachers based on their experiences with the phenomenon "teacher leadership". The study group of the research consists of six school administrators and 10 teachers working in public and private primary schools in Ankara during the 2019-2020 academic year. The maximum diversity sampling technique was used in the study, variables such as gender, age, educational status, position, branch, professional seniority, seniority in the school, and the type of school were taken as a source of diversity in determining the school administrators and teachers. In the research, semi-structured interview forms consisting of 7 demographic and 8 open-ended questions developed by the researchers were used as data collection tools. Some questions in the interview form are as such; "What do you think about the characteristics should teacher leaders have?", "What are the roles of teacher leaders?" Face-toface interviews were conducted with both teachers and administrators. One interview lasted approximately 30 minutes. Content analysis was used in the analysis of the data. While quoting the participants' views, they were coded by giving gender-appropriate name codes in order to ensure the confidentiality of school administrators and teachers.

\section{Findings}

As for the meaning of the teacher leadership, participants determined two categories which focused on individual qualities and professional qualities. Participants also determined that teacher leaders should have technical, personal and conceptual characteristics. The roles of teacher leaders were emerged out as support for professional development, instructional leadership, transformational leadership, cooperation, mentoring, fundraising and the other categories. When the answers of the participants were examined for the contributions of teacher leaders to school development, it was determined that their views were mostly focused in the categories of academic success, social activities, and healthy school climate and school life quality. The barriers for being a teacher leader are determined as follows; bureaucratic, school administration and colleagues' barriers and the other. As for suggestions the participants expressed their opinions in terms of the administrator, teacher and other categories. 


\section{Discussion}

It is striking that participants generally used positive concepts in explaining teacher leadership. It was concluded that teacher leaders should have a unifying and innovative feature at school. It can be said that teacher leaders are people who have positive qualities that will carry the school forward. It can be concluded that teachers who exhibit leadership behaviors in schools play an active role in social activities and projects and attach importance to professional development in cooperation. The participants stated that the presence of teacher leaders in their schools would affect the internalization and strengthening of the image of their schools, a healthier organizational climate, thus increasing the interaction between teachers. It can be accepted that the greatest contribution of teacher leadership for the improvement of schools is the increase in academic success of the school and the cooperation of the school climate. Based on the results of the research, it can be said that a climate that enables teachers to use new methods, no bureaucratic clumsiness, and cooperation between colleagues, are important. It is also important for teachers to be more autonomous in their work environments, in terms of the applicability of teacher leadership, since they are educated. 
EK 1: Etik Kurul Onayı

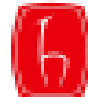

T.C.

HACETTEPE. CNIVERSITESI

Rechı̈̌riak

Sey : : 35853172-300

Kom : Ouge AYVALI HK.

\section{EGITIM BALIMLFRA ENSTITCSD MODORLCGONE}

thi : 24.01 2019 Larili ve 51944218-30060000428876 sayllu yazux.

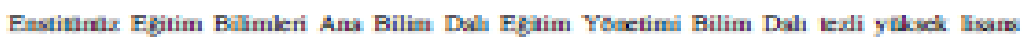

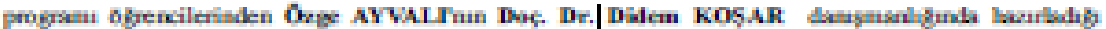

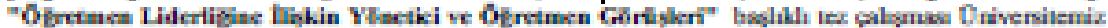

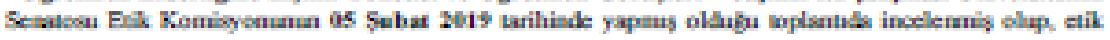

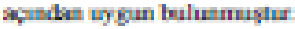

Rilgilerinidi ve geredini sayglanmla rica olerim

e-imulatur

Proc De Ralime Mers NoHutcr:

Reknor Yastmets: 